\title{
A Study on Growth Performance of Nandanam II Turkey under Intensive System
}

\author{
S. Ilavarasan*, S. Jaishankar, T. Lurthu Reetha, A. Sheeba and R. Jyothi Priya
}

Tamil Nadu Veterinary and Animal Sciences University-Regional Research and Educational Centre - Pudukkottai, India

*Corresponding author

\section{A B S T R A C T}

\section{Keywords}

Nandanam II turkey, Body weight and Feed conversion ratio

\section{Article Info}

Accepted: 25 November 2020 Available Online: 10 December 2020
A study was carried out to determine the growth performance of Nandanam II turkeys under intensive systems of management in TANUVAS - RREC, Pudukkottai, Tamil Nadu. A commercial breed of new strain turkey, Nandanam -II turkey was used. In this study, Birds were kept in an enclosed deep litter poultry house (intensive system) in TANUVAS -RREC Turkey unit from 0 to 8 weeks (brooder) and 9 to 16 weeks in grower shed and fed with turkey brooder and grower mash and supplement diets respectively. Parameters assessed in this study was hatch weight, body weight at 4 weeks intervals upto $16^{\text {th }}$ week, feed intake, feed conversion ratio were recorded. Results of feed intake and body weight showed a consistent increase with increase in age. Performance results showed that turkey had $50.51 \pm 0.41 \mathrm{gm}, \quad 391.71 \pm 4.60 \mathrm{gm}, \quad 1289.75 \pm 15.84 \mathrm{gm}$, $2235.15 \pm 16.43 \mathrm{gm}, 3209.42 \pm 34.73 \mathrm{gm}$ hatching weight, fourth week body weight, eighth week body weight, twelth week body weight, sixteenth week body weight, , respectively. It can be concluded that, the rearing of Nandanam -II turkey is possible under intensive system of rearing in the Pudukkottai district.

\section{Introduction}

Deficiency of poultry meat and eggs in the country are $78.91 \%$ and $65.38 \%$ respectively per person per year (FAO/APHCA, 2012; Saleque, 2010; Das et al., 2008). The commercial poultry sector has got an industrial shape within the period of 3 decades and becomes one of the leading enterprises contributing lot in national economic growth, followed by garments. Commercial broiler and layer farming have emerged during the last quarter of 20th century and then flourishes within short period. Expansion of poultry farming, both at commercial and domestic levels, is meant absolutely the expansion of modern chicken strains of layer and broiler. In addition to chicken, the other poultry species that traditionally rearing and kept by our rural poultry keepers are quail, geese, pigeon and guinea fowl. The growth, development and expansion of above mentioned species of specialized fowls are remained unchanged for decade after decade as because of a little or no attention has been paid to them. 
In such a situation, it may be pertinent to focus on the rearing of alternative poultry species. One of the best choices may be the turkey (Meleagris gallopavo), which has been recently introduced and slowly expanding in small scale throughout the country. Turkey (Meleagris gallopavo) is a large gallinaceous bird of the family Meleagridae and occupies an important global position next to chicken and duck approximately $5 \%$ of world poultry population (Besbes, 2009).More importantly, turkeys have unique and remarkable phenomena in adaptability to wide range of climatic conditions and can be raised successfully almost everywhere in the world if they are well fed and protected against diseases, predators and adverse weather conditions (Bhanja and Majumdar, 2001).Turkey is more resistant to disease compared to other poultry species like chicken, duck, and quail. It has also been reported that mortality rate of turkey is very low compared to other poultry bird (Sampath, 2012).

Turkey farming in India has now shifted from backyard farming to scientific intensive farming due to change in market priorities and consumer preference. Considering the future of economic and livelihood potential of practicing Turkey farmers, Tamil Nadu Veterinary and Animal Sciences University, Chennai has released a new strain, Nandanam Turkey-1 for commercial rearing. It is developed with the base population of Nondescript and Beltsville small white turkeys for the improvements in all the economic traits.

Certain traits such as hatch weight, weekly body weight, feed consumption, at different ages will help in understanding production potential of Nandanam turkey. Therefore, the main objective of our study is to investigate the growth performance of Nandanam II turkey under intensive system of rearing.

\section{Materials and Methods}

The study was conducted at Turkey unit of TamilNadu Veterinary and Animal Sciences University- Regional Research and Education Centre, Pudukkottai, Tamil Nadu, India during the year 2019-20.A total of 100day-old poults were obtained in one hatch from turkey breeding stock. Each birds were individually weighed and wing banded. Birds were fed pre brooder mash diet up to four weeks of age, brooder mash diet from five to eight weeks of age. After eight weeks of age, birds were transferred to the deep litter house and were fed with grower mash diet up to 16 weeks of age. Feed was supplied twice daily, once in the morning and another at afternoon. Fresh and clean drinking water was made available at all the times. Poults were vaccinated with R2B1 at 7 days of age and Lasota dose was administered at 28 days of age in the farm house against Newcastle disease. Fowl pox vaccine was administrated at 6 weeks of age through the puncturing of wing web $(w / w)$. Then, ND Killed vaccine was vaccinated at 2 months of age and repeated every three months. Individual bird body weight was recorded at day one and subsequently on four weekly intervals up to 16 weeks of age. Daily mortality, hatch weight, body weight at four weeks intervals upto $16^{\text {th }}$ week of age and feed conversion ratio were recorded.

\section{Results and Discussion}

The mean body weight obtained from Nandanam Turkey-II from0, 4, 8, 12, and 16 th weeks of age are presented in Table 1.

\section{Body weights}

At hatch the mean body weight of Nandanam turkey-II was 50.51 \pm 0.41 . Four weeks intervals of mean body weight at $4^{\text {th }}, 8^{\text {th }}, 12^{\text {th }}$ and $16^{\text {th }}$ week were $391.71 \pm 4.60,1289.75$ $\pm 15.84, \quad 2235.15 \pm 16.43, \quad 3209.42 \pm 34.73$ 
respectively. The results were in accordance with the report of Roberson et al., (2003) who observed increased body weights in sexes of different commercial strains.

\section{Sex ratio}

The male and female was 1:03 which is about $48.98 \%$ because of very much useful for better reproductive rates. It might be of 1.04 like
Sudan where male and female ratio maintained at 1:046 (Osama et al., 2013). It depends on the farmers' experience which combination is suitable for successful reproductive. Even though a good ratio of male and female has less productivity because of absence of frequent mating, heavyweight of male and disturbance during mating (Osama et al., 2013).

Table.1a Mean values on body weights (g) of Nandanam turkey -II

\begin{tabular}{|l|l|l|l|l|l|}
\hline Breed & Hatch weight & 4 WEEK (g) & 8 WEEK (g) & 12 WEEK (g) & 16 WEEK (g) \\
\hline Nandanam II & $50.51 \pm 0.411$ & $391.71 \pm 4.60$ & $1289.75 \pm 15.84$ & $2235.15 \pm 16.43$ & $3209.42 \pm 34.73$ \\
\hline
\end{tabular}

Table 1b Data on male: female ratios, average body weight $(\mathrm{kg})$ at 16 th week and feed conversion ratio

\begin{tabular}{|c|c|c|}
\hline Sl.no & Particulars & Value \\
\hline $\mathbf{1 .}$ & No of Males & 52 \\
\hline $\mathbf{2 .}$ & No of Females & 48 \\
\hline $\mathbf{3 .}$ & Average body weight of males at $16^{\text {th }}$ week & 3.32 \\
\hline $\mathbf{4 .}$ & Average body weight of Females at $16^{\text {th }}$ week & 3.08 \\
\hline $\mathbf{5 .}$ & Feed conversion ratio & 3.02 \\
\hline $\mathbf{6 .}$ & Livability percentage & 100 \\
\hline
\end{tabular}

\section{Feed conversion ratio}

The feed conversion ratio of the $16^{\text {th }}$ week age Nandanam II turkey is 3.02. The turkey requires high protein and other nutrients in their diets. Thus, feed cost represents halve to two-thirds of the total costs in a poultry production system (Mbanasor and Sampson, 2004), therefore it is necessary to identify the animals who eat less but perform at the same level as their contemporaries. Turkeys are good foragers and it could reduce feeding cost through obtain added nutrients from forage because they are better able to digest fiber due to larger microbial population in their digestive tracts (Brad et al., 2010). highest feed was required for a 20+ weeks aged chick who takes on an average 192.13 grams feed per day, followed by 10-20 weeks aged turkey who takes on an average 132.54 grams feed per day. There is no specific feeding standard for turkey. Farmers used to feed their turkey according to broiler and layer feeding manual (Rahabul, 2018).

From this study, it is concluded that the rearing of Nandanam -II turkey is possible under intensive system of rearing in the Pudukkottai district.

\section{References}

Besbes B, 2009. Genotype evaluation and breeding of poultry for performance under sub-optimal village conditions. World's Poultry Science Journal, 65: 260-271.

Brad, B., Elena, T., \& Gernat, A. (2010). 
Maximizing foraging behavior, University of Florida, IFAS Extension, pp: 12-13.

Bhanja, S.K. and Majumdar, S., 2001. Formulation of turkey feed. In: Modern turkey production and management (AKD Roy, ed). Turkey Research Unit, Central Avian Research Institute, Izatnager, India. pp. 49-52.

Das, S.C., Chowdhury, S.D., Khatun, A., Isobe, N., Nishibori, M., Yoshimura, Y., 2008. Poultry production profile and expected future projection in Bangladesh. World's Poultry Science Journal, 64: 107-125.

FAO/APHCA, 2012;Food and Agriculture Organization 2012. FAOSTAT database. Accessed Sep. 27, 2012. http://faostat.fao.org.GilD. J. Leighto A. T.Jr. 1984. Effects of light environment and population density on growth performance of male turkeys. Poultry Science, 63: 1314

Mbanasor, J. A., Sampson, A. (2004). Socioeconomic Determinants of Turkey Production among Nigerian Soldiers. International Journal of Poultry Science, $3(8)$, 497- 502.https://doi.org/10.4314/dai.v16i3.15 671

Rahabul, I. M. (2018). Rearing system, management practice, problems and prospects of turkey farming in different turkey farms of RangpurSadarUpazila, Internship program for Doctors of Veterinary Medicine (DVM) Degree in Chittagong Veterinary and Animal Sciences University (CVASU), Bangladesh

Saleque, 2010;Saleque, M.A., 2010. Livestock and Livelihood- The role of BRAC in livestock development in Bangladesh, presented in Review of Livestock Research Programs and Preparation of Future Research organized by BRAC.

Sampath, K. T. (2012). Turkey farming: A profitable enterprise, National Institute of Animal Nutrition and Physiology, Adugodi Bangalore, India, 21, 2.

Osama, E. Y., Salim, G., Hassan, A. H. A., \& Bushara, A. B. (2013). A Study on Turkey (Meleagris gallopavo) Raising in the Sudan. Journal of Applied and Industrial Sciences, 1, 11-15

\section{How to cite this article:}

Ilavarasan, S., S. Jaishankar, T. Lurthu Reetha, A. Sheeba and Jyothi priya, R. 2020. A Study on Growth Performance of Nandanam II Turkey under Intensive System. Int.J.Curr.Microbiol.App.Sci. 9(12): 3520-3523. doi: https://doi.org/10.20546/ijcmas.2020.912.418 